Journal Home Page:

http://perlinguam.journals.ac.za
Per Linguam
A Journal for Language Learning Tydskrif vir Taalaanleer

\title{
DEVELOPING STANDARDS USING THE LANGUAGE OF TEACHING AND LEARNING
}

\author{
H Bolton \\ South African Qualifications Authority (SAQA)
}

A recent paper by the author argued that educational standards inhered at least partly in the competence levels of learners, and that these competences mirrored those of their teachers. In the paper, the development of standards through quality teaching and learning were addressed, attempting to show that certain teaching-and-learning features have been linked to learner success across a range of contexts, including secondary school arts and science classrooms and a vocational course across a variety of social class contexts. Evidence was presented for the argument that the explication of evaluation criteria was central in all the teaching-and-learning practices linked to high levels of learner competence in a number of studies, and that five additional features were present in these practices serving to make possible elaboration of the necessary criteria. The current paper presents an in-depth linguistic analysis of some of the ways in which teachers have elaborated evaluation criteria, examining the relationship between instructional and regulative discourse in the classroom and how particular configurations of the two serve to enable clarification of qualities to be assessed, for learners. The paper closes by pointing to some implications for policy and practice.

\section{INTRODUCTION}

It has been argued elsewhere (Bolton, 2012) that the quality of teaching-and-learning processes and associated levels of learner competence are integral to the development of educational standards. The quality of teaching-learning has been expressed in terms of the specific teaching-learning features linked to high levels of learner achievement across a range of knowledge areas and social contexts (Bolton, 2012). While consideration of a number of studies suggests a large overlap between the teaching-learning features linked to learner success across knowledge areas and socio-economic contexts, the specific basket of features linked to high learner competence in particular knowledge areas and social contexts differs slightly.

While it may be important to note these particular features, more important still is understanding of a language of description for teaching and learning that provides means to manipulate, consciously and systematically, aspects of teaching-learning practice towards building learner competence levels in particular knowledge areas and social class contexts. Furthermore, this language of description is potentially useful for curriculum and learning materials design as well as for the act of teaching and learning itself. 
First, I will consider some theoretical tools useful for a language of description that provides flexibility of teaching-and-learning across learning and social contexts.

Using a language of description based on the theoretical tools discussed, the commonalities and differences in teaching-and-learning associated with learner success across a variety of contexts are noted. Patterns are drawn by pointing to a cluster of Portuguese studies focusing on teaching-learning in intermediate-level science classrooms in a range of social class contexts (Domingos, 1987, 1989; Morais et al., 1992, 1995); parallel research into arts classrooms in secondary schools across a range of social contexts in South Africa (Bolton, 2005, 2009, 2012); and a study of the teaching-learning process in an electrical-skills classroom and workshop for youth otherwise not studying or employed and from a low socioeconomic area, in a Further Education and Training (FET) college also in South Africa (Wedekind \& Watson, 2012).

The main criterion in teaching-and-learning linked to learner success in these studies appears to be clear elaboration of evaluation criteria - the explication of criteria according to which learners are assessed and in relation to which they need to demonstrate competence. Five other areas of teaching-learning features seem to serve to enable this elaboration of criteria, these other features comprising a mix of specialised-knowledge-related (instructional) and socio-affective (regulative) aspects. In the current paper, I will examine the relationship between the instructional and the regulative in detailed linguistic analysis of selected teacherlearner interactions in the classrooms studied, pointing to the kinds of linguistic and embodied interactions linked to high levels of learner competence. I will conclude with suggestions of implications for policy and practice in the current education and training context in South Africa.

\section{TOOLS FOR FEXIBILITY OF TEACHING AND LEARNING ACROSS CONTEXTS}

Given the acknowledged inter-connectedness of activities, their socio-material locations (Fenwick, 2010a, 2010b, 2010c) and the systems of which they are part (Engeström, 1987, 2001), any conceptual tools for flexible teaching-and-learning ideally need to account for micro-level teaching-learning interactions, macro-level contextual features and relationships between the two aspects. Engeström's (1987) cultural historical activity theory triangle, with the subject's move towards its objective mediated by 'tools', 'rules', 'communities of practice' and 'divisions of labour', is useful in this regard. The scope of the present paper permits only an in-depth look only at the divisions of labour in teaching-and-learning contexts - at power and control relations in the classroom or workshop context.

While in the past several studies pointed to differing curricula, teaching-learning processes, and learner competence levels, across different social contexts (e.g., Anyon, 1981; Coleman, 1966; Connell, 1974; Da Silva, 1988; Pedro, 1981), others more recently have noted differential performance levels in socially similar contexts (e.g., Taylor et al., 2003). Three sets of studies in which learner competence levels in comparable social contexts are associated with particular power and control relations are of interest here.

First, a cluster of studies dealing specifically with teaching-and-learning associated with learner competence in science (Domingos, 1987, 1989; Ferreira \& Morais, 2008; Morais, 1998; Morais \& Camara, 1997; Morais \& Neves, 1997; Morais \& Pires, 2002; Morais \& Rocha, 1997; Morais et al., 1992, 1995) and second, parallel research into arts classes at 
school level (Bolton, 2005, 2009, 2012) draw on the concept of 'pedagogic code' (Bernstein, 1971, 1975, 1981, 1990, 1996). Notwithstanding criticisms (Harker \& May, 1993) ${ }^{i}$, it is argued that pedagogic code is useful both for linking macro- and micro-levels of analysis and for enabling conscious manipulation of power and control relations in the teaching-learning process to enhance learner achievements. A third body of research, of which a case study of teaching-learning in a successful college-level electrical skills classroom and workshop is part (Wedekind \& Watson, 2012), uses a broader range of conceptual tools but also touches on and widens Bernstein's (1996) related ideas of instructional and regulative.

Importantly for the current paper, these concepts enable analysis of the teaching-learning process in terms of power and control relations within and constituted by them, as both 'a relay' (a mechanism) and 'the relayed' (the message). At an abstract level, Bernstein (1996) used the specialised concepts of classification and framing. Classification - which relates to the distribution of power - denotes the extent to which categories are separated or intermingled. It has been argued elsewhere (Bolton, 2012) that these categories can be anything from the physical sites in which teaching-learning occurs to the spaces learners are encouraged to utilise to the kinds of communities and learning experiences learners are exposed to and other aspects of teaching and learning. The key idea is that categories (sites of learning, agents of learning, different subject discourses, etc.) can be 'separate' (of a uniform type) or 'mixed' (of several types). When classification is 'strong', categories will have clearly distinguishable identities and specialised rules of internal relations; when it is 'weak', categories will be less easily distinguishable, with less specialised internal relations (Bernstein, 1996). In the science and arts studies noted, the classification of discourses in the teaching-learning contexts studied, that is teaching-learning spaces, and agents involved in the teaching-learning process were analysed.

Framing comprises control of communications in the teaching-learning process and context. It is analytically separable from power relations but is not distinguishable in practice (Bernstein, 1996). According to Bernstein (1996, 27-28), framing regulates both the 'rules of the social order' (the hierarchical rules; 'regulative discourse') and 'the rules of the discursive order' ('instructional discourse').

In the studies mentioned in this paper, regulative discourse refers to learners' 'conduct, character, and manner'; and the extent to which relations between the teacher and learners are hierarchical (Bernstein, 1996: 27-28). Instructional discourse relates to specialised knowledge and skills to be taught and learned. The idea of framing the selection, sequencing and pacing of instructional content, and using evaluation criteria by means of which learners' texts (any aspects attracting evaluation) are evaluated refers here to the extent to which these aspects are tightly teacher-controlled and driven and the degree to which learners are apparently given control of these aspects. When the teacher has explicit control, framing is said to be 'strong', while with 'weak' framing, learners have more apparent control.

All of these aspects were analysed in the science and arts studies noted. The studies show that teachers can selectively adopt different communication codes (Bolton, 2005, 2009), and actively be taught to use differing codes in different social contexts (Morais et al., 1992, 1995).

Given the less-developed language of description of vocational teaching-and-learning in the Anglophone world, researchers turn to more general theories of teaching and learning and 
explore their applicability in vocational settings (Wedekind \& Watson, 2012). They draw, in particular, on Hattie's $(2003,2009)$ meta-analyses of 50000 studies into learner achievement, which yielded 134 teaching-learning effects on this achievement. It is enlightening to relate the seven influential effects relating to teaching and learning identified by Wedekind and Watson (2012) - teacher-feedback, teacher-student relations, direct instruction, mastery learning, classroom cohesion and management, and peer tutoring - to teaching-learning characteristics relating to analytical categories derived from Bernstein's (1996) notions of power and control in terms of 'classification' and 'framing', as instructional and regulative parallels emerge (Bolton, 2012).

\section{Teaching and learning linked to learner competence across learning and social contexts}

High levels of conceptual demand, although associated with high levels of learner achievement in both art and science are on their own insufficient for high achievement (Bolton, 2005, 2009; Morais et al., 1992, 1995). It is known that apart from teachers' levels of disciplinary knowledge and skill (which need to be high), certain pedagogic features are crucial for the transfer and learner acquisition of complex cognitive competences in science (Domingos, 1987; Ferreira \& Morais, 2008; Morais, 1998; Morais \& Camara, 1997; Morais \& Neves, 1997; Morais \& Pires, 2002; Morais \& Rocha, 1997; Morais et al., 1992, 1995) ${ }^{\mathrm{ii}}$. It was found that despite the differences in knowledge areas and school levels, almost all of these teaching-learning process features were also associated with acquisition of complex skills in the arts (Bolton, 2005, 2009). Strong parallels were also found in a case study of teaching and learning in a vocational electrical skills course at college level (Bolton, 2012, drawing on Wedekind \& Watson, 2012). In addition, while particular teaching-learning features were linked to success for all learners, slightly differing features were linked to high competence levels for learners in differing social class groups.

In summary ${ }^{\mathrm{iii}}$, as noted, particular teaching-learning features linked to the achievement of high percentage grades in art and science include high levels of conceptual demand and a high degree of clarification and explication of evaluation criteria. Five other aspects of teachingand-learning thought to facilitate the clarification of evaluation criteria include first, immersion in or high exposure to specialised discourses (strong classification of discourses) and second, weak classification of teacher-learner spaces - where teachers inter-mingle in learners' spaces and communicate with them continually - contributes to learner success. A third feature is respectful rather than authoritarian communication relations. A fourth constitutes strong teacher control of the sequencing and pacing of work covered, which together create appropriately sized steps to provide scaffolding for learners from their existing knowledge to positions of increased specialised knowledge. A final aspect is learner selection of secondary (non-key) aspects of projects, which appears to enhance their engagement with their work. These qualities of direct instruction, frequent feedback of a variety of kinds, mastery-learning approach, respectful communication relations, and frequently inter-mingled use of teacher-learner and learner-learner spaces were observed, during a case study, to be mirrored in the practices of a respected lecturer in an artisan course at a FET college (Wedekind \& Watson, 2012).

In addition, in the art classes studied, teaching and learning linked to success in upper middleclass contexts was fast-paced and business like, with strong differentiation of individual learners and high levels of teacher control of sound and work focus. In contrast, pedagogy linked to success in lower middle-class contexts was more relaxed and slower-paced, teachers 
addressed learners in groups, and there was apparently high learner determination of sound levels and work focus. In these classrooms, it appeared that learners-as-a-collective and lively learner-learner interaction mediated and assisted in the transfer of specialised knowledge. The ethos in the college classroom was described as being ordered and well-managed but respectful, relaxed and polite, with high levels of lecturer-learner and learner-learner dialogue, and opportunities for learner pacing where needed.

The main difference between teaching-and-learning linked to high levels of learner competence, in the science and art studies respectively, was increased teacher control of the sequencing of micro-level steps in processes followed in the high-achieving art classes relative to that in the sciences, in all social class contexts studied (Bolton, 2005, 2009). The researcher concluded that in knowledge areas where there are several 'right' ways of approaching learning and several 'solutions', tightly controlled processes are essential for ensuring that learners follow acceptable learning routes.

Important to this discussion is the linguistic aspect of the relationship between instructional and regulative components of these 'baskets' of teaching-learning features linked to high learner competence. The scope of this paper does not permit analysis of aspects such as embodied exposure to specialised discourses; use of space in the teaching-learning context; and the selection, sequencing, and pacing of instructional content covered. The focus here is on detailed linguistic analysis of teacher-learner interactions for explication of instructional (specialised knowledge-specific) evaluation criteria, and the relationship between this dialogue and regulative discourse in the classrooms studied.

\section{The instructional and the regulative: Some linguistic detail}

This section of the paper sketches regulative discourse representing differing kinds of social relations between teachers and learners and instructional discourse in which evaluation criteria were made clear, to differing extents, in a number of studies.

\section{Brief analysis of regulative discourse in the selected studies}

Regulative discourse has been operationalised in empirical research in a variety of ways. Drawing on Bernstein (1971: 152-160), Morais and Neves (1997) r) considered social relations 'horizontal' or 'respectful' when teachers' regulative comments were characterised as 'inter-personal', comprising personal appeals, emphasising advantages and disadvantages of actions and leaving hierarchical teacher-learner relations implicit. Such comments could take the form of requests and statements with explanations. Examples are 'Please sit down'; and 'You should be seated if you're going to see properly'. Framing of hierarchical rules is categorised as weak when the norms of social conduct are not indicated, but are left implicit, and personal appeals when the limits of norms are transgressed (Bernstein, 1971: 152-160). Framing is seen as being strong or 'hierarchical' when regulative comments are 'positional' (based on social status) or 'imperative', when they emphasise group characteristics or show clear displays of authority (Bernstein, 1971: 152-160). Typical examples are 'Why aren't you sitting down?' and 'Sit down'.

These concepts require elaboration in order to understand the relationship between the instructional and the regulative more fully. Regulative communications observed in the arts study (Bolton, 2005, 2009) presented three features thought to have potential to shape this 
relationship. First, neither explication nor the leaving implicit of norms was necessarily coupled with inter-personal or positional communications: the degree to which comments were inter-personal or positional varied independently of the spelling-out of norms.

Second, positional communications issued from different positions, one 'voice' being that of 'secondary school teacher'. Comments such as "Why're you all wandering around? Sit down now, the lesson has started" derive status from the teacher's position in the school system. Another perceived voice was that of (in this case an arts-trained) specialist. The status of comments such as 'You need to make more tones'; 'Work on your negative spaces'; 'Keep that whole idea of the formalist composition in mind' - 'you must think in terms of balance and focal point' and 'Vary your brush marks' were derived more from knowledge of art tradition than from authority vested by the school.

A third consideration was that teachers often gave reasons for regulative suggestions, whether the comments were made in personalised or in positional or in imperative modes.

A scheme for analysing teachers' regulative comments was devised, taking these features into account (Bolton, 2005) ${ }^{\mathrm{iv}}$. The unit of analysis was the teacher-learner interaction, a single interaction being the sum of all teacher-learner communications (with individuals or groups) until the teacher moved to subsequent learners. Teacher-learner interactions were scanned for presence and type of norms, learner 'transgressions', and teacher responses to learners' transgressions. Norms were categorised as 'implicit'; 'art-conduct norms'; and 'socialconduct norms'. Learner 'transgressions' constituted undesirable behaviours, whether social or art-conduct related ${ }^{\mathrm{v}}$. Teacher responses to learner transgressions were categorised as 'interpersonal/art-positional' when they appealed to individuals, included respectful reasoning, or drew on art norms; 'social-positional/imperative' when they were based on social status or authoritative commanding; and 'mixed' where there were both types of comments. The following extracts are examples of inter-personal and art-positional communications respectively.

T: (to a learner who hadn't done much work for several lessons, was way behind the rest of the class, and had discussed different options for background imagery at length with the teacher on several previous occasions) Background?

L: I'm still thinking

T: Can I see the notes you've made on all the things you've thought about? What've you thought about so far?

L: (Showing a sketch he is clearly not satisfied with) The South African flag's stupid

T: $\quad$ I agree - unless it's really like whipped and twisted - and really interesting in terms of shape. You could use that

and

T: $\quad$ You still need your 6B pencils - it's basically all coming out silver now

L: (nods) 
T: $\quad$ You still need to use your 6B to get your dark colours [art norm, art positional comment]

The following two examples show a 'social positional' comment, where justification is based on social norms and an 'imperative' command with no justification, respectively.

T: (to a learner after reminding the class that work was due) Okay, what're you doing now Rick?

L: $\quad$ (indistinct - the learner was rapidly trying to complete his work)

T: You give it in as it is. It's time now; if you don't come to school, that's your problem [social norm, social-positional comment]

and

T: (to a learner not working after the start of a lesson) At the back there, can you please get some work done now? [inter-personal comment] Put your bag on the floor and get going [norm implicit; imperative comment]

By using the categorisation in Table 1 below, it was possible to record comments in all teacher-learner interactions in a particular period and to characterise the preferred or habitual modes of particular teachers ${ }^{\mathrm{vi}}$. 
Table 1: Scheme to categorise teacher's regulative comments according to hierarchical character and use of norm (Bolton, 2005)

\begin{tabular}{|l|l|l|l|l|}
\hline & $\begin{array}{l}\text { No learner } \\
\text { transgression }\end{array}$ & $\begin{array}{l}\text { Social or art- } \\
\text { related } \\
\text { transgression } \\
\text { with inter- } \\
\text { personal/art- } \\
\text { positional } \\
\text { teacher } \\
\text { comment }\end{array}$ & $\begin{array}{l}\text { Social or art- } \\
\text { related } \\
\text { transgression } \\
\text { with social- } \\
\text { positional/imp } \\
\text { erative teacher } \\
\text { comment }\end{array}$ & $\begin{array}{l}\text { Social or art- } \\
\text { related } \\
\text { transgression } \\
\text { with mixed- } \\
\text { mode teacher } \\
\text { comment }\end{array}$ \\
\hline $\begin{array}{l}\text { Norm/s } \\
\text { implicit }\end{array}$ & & & & \\
\hline $\begin{array}{l}\text { Art norm/s, } \\
\text { with or without } \\
\text { implicit norms }\end{array}$ & & & & \\
\hline $\begin{array}{l}\text { Social norm/s, } \\
\text { with or without } \\
\text { implicit norms }\end{array}$ & & & & \\
\hline $\begin{array}{l}\text { Mixed norms, } \\
\text { with or without } \\
\text { implicit norms }\end{array}$ & & & & \\
\hline
\end{tabular}

All of the art teachers studied used the full range of the types of comments categorised in Table 1 (Bolton, 2005). However, when all categories considered 'respectful' rather than 'authoritarian', namely those with implicit norms, art-conduct norms, and inter-personal or specialised art-positional teacher responses to 'transgressions' were combined, there were clear differences between teachers. Framing of regulative mode was thus based on the relative percentages of 'respectful' interactions (with implicit/specialised conduct norms and interpersonal/specialised-positional teacher responses) versus 'authoritarian' comments (with implicit or explicit social norms and social-positional or imperative responses) in relation to learner actions.

Regulative mode is essentially about the degree to which teachers adopt the role of 'teacher' and focus on personal or social conduct, social norms, and imperative communications, as opposed to taking on the role of 'facilitator' and focusing on specialised conduct, norms in specialised areas of learning, and inter-personal/specialist-positional communications. In teaching-learning contexts linked to high learner competence, the regulative mode was that characterised here as 'respectful' (Bolton, 2005: 155-162.). 
In the case of the vocational classroom and workshop studied (Wedekind \& Watson, 2012), in the introductory session and demonstrations and practical applications that followed, the lecturer stressed essential artisanal habits not directly related to the current learning but linked to learners' preparation for being employable as artisans. He reminded learners, for example, to be neat in appearance and remember safety rules. There was strong framing (teacher control) of the regulative discourse relating to preparedness of the learners for the world of work: posters with quotes such as 'It is rude not to knock on someone's door. Please knock and wait for someone to open the door for you' and 'Quality is never an accident. It is always the result of high intention, intelligent direction, sincere effort and skill-full execution' were displayed. Regulative discourse was task-oriented rather than being based on the lecturer's authority; the lecturer reminded learners of aspects such as remembering skills with handtools learned earlier, and that frequent practice would lead to mastery. The respectful teacherlearner relations in high-achieving art and science classes studied were reflected in the artisan classroom and workshop, expressed as the lecturer's 'ability to relate to his students' in a cooperative 'respectful yet relaxed and tolerant' atmosphere (Wedekind \& Watson, 2012: 10, 14).

\section{Instructional discourse: Explication of evaluation criteria}

Evaluation criteria are potentially explicated - clarified, explained, and elaborated - through teacher-learner dialogue and demonstration. In both the set of high-achieving practical art classes studied (Bolton, 2005, 2009) and the respected electrical skills class observed (Wedekind \& Watson, 2012), project requirements (including assessment criteria) were introduced and their assessment criteria explicitly discussed and demonstrated in project introductions. In the art classes, exemplars were provided from the History of Art and previous successful learners or by prior visits to art galleries; in the Installing wire-ways class $^{\mathrm{vii}}$, the lecturer started by going over theoretical components which would require subsequent application, as set out in the unit standards and objectives for the module in the official South African Qualifications Authority (SAQA) document - to give students the 'bigger picture' in which their exercise was located. This verbal explanation was followed with a video-recorded (visual) demonstration of how to bend electrical conduits, and a further practical demonstration with a commentary, emphasising the necessary skills, by the lecturer.

Evaluation criteria are potentially further explicated through dialogue and demonstration as learners carry out exercises. In the art classes, teachers gave feedback in relation to learner choices in the process of image-making: while individual learners needed to make the ideasrelated, design, and technical-craft choices within project requirements themselves, teachers in high-achieving school classes discussed these choices at length on an on-going basis by extending learner selections and elaborating assessment criteria or criteria worthy of evaluation.

Extension of learner selections was observed in four ways, first, as affirmation of learner selections as, for example, when a learner had chosen to work with powder paints, with 'it's so much easier to work with powder paints', or with 'that's nice'. Extension also comprised clarifying what learners had decided to do, such as in the following excerpt, where the learner approached the teacher, asking if he could make a final artwork from a composition he had sketched.

\section{L: $\quad$ Sir can I do this one here?}


T: $\quad$ But are you happy with that composition? Is that finished?

CML: No - I was going to do more stuff in there (points to artwork)

Third, a teacher can extend learners' selections by encouraging continuation of something already begun, as in: 'You're doing fine - just bring in some different tones ... just like you've done here (points to area on learner's drawing)'. Fourth, the teacher can extend learners' selections by adding new ideas, as in the following excerpt where the learner shows the teacher an artwork featuring a self-portrait surrounded by cut-out sketches of butterflies in various stages of maturity as visual metaphors for personal growth.

T: [You need to think about] developing things spatially and also in some sort of time sequence.... You've got to think if you're going to suspend those [points to sketches of butterflies] or mount them. Or ... stick them down.... I mean you can think of some sort of metamorphosis. Like these [points to nose and cheeks on drawn self-portrait] becoming the body of the butterfly - your nose - and from there, you know, wings extending outwards.... And then the environment - are you a person that likes nature? Are you a person that doesn't like nature? ... Butterfly nymphs - we find them in beautiful places where nature abounds - you could do a contrast in your drawing of city and barren spaces, and very lush areas. And you could possibly think of ... bringing ... something transparent over it ... These eyes [points to eyes in drawn selfportrait] can become the eyes on the butterfly's wings ... So I think what you need to do is you need to look at the complete form of a butterfly and you need to think of how you can relate it to that [points to drawn face] ... even if you start working on transparent paper ... where you cut out things and reveal parts of yourself [the drawn face] ...

Creating analytical categories for the explication of evaluation in the research (Bolton, 2005: 170-176 page number) required a 'continuum of degrees of clarity'. Criteria in the art classes were said to be 'clear' when presented as specific routes of progression for learners. The critical feature for defining clarity was the narrowness of options presented to learners: in what were categorised as clear evaluations, the teacher presented relatively specific options within which learners were bounded and barred from possibilities external to this. Criteria were said to be 'unclear' when several options were available to learners, and when ideas about subject matter content were not verbally elaborated. When criteria were unclear, learners could potentially make multiple interpretations. A variety of conditions conceivably narrowed the possibilities of interpretation by learners and served to clarify criteria; some examples from the study (Bolton, 2005) are delineated below.

Criteria were clearest when specific principles or features to be evaluated and art-specific behaviours were explained to learners together with the showing of visual examples in the form required An example follows. When teachers and learners clearly shared visual understanding, there was no need to provide visual imagery.

T: What's wrong with this? [teacher points to a sketch on the blackboard showing overlapping outlines of objects, when learners were engaged in a project in which they were meant to use objects as starting points, and then abstract the objects so that only lines, colours and tones remained to suggest three-dimensional space] 
L: $\quad$ You can see the objects

L2: It's overlapping

T: What's in front there? ... Is anyone going to argue with me ... the bone shape is in front, isn't it?

L: $\quad$ Yes

L3: Ja

T: $\quad$ And the chair shape's behind.... Why does the mind tell you that?

L2: Because the bone's on top of the chair

T: How d'you know it's on top - it's not, it's chalk on board ... it's a flat surface

L4: It's overlapping

T: It overlaps.... Whenever it overlaps, it's obvious this object is in front of that object [spoken while pointing to the sketch on the board.]... Your mind tells you because of overlapping ... You must confuse the viewer - [as to] what's in front and what's not [specific art-conduct]. If you do this [alters sketch on board, removing lines that provide the illusion that one object is in front of the other] [visual example in the form required] you have no idea, you wouldn't know ... what's in front, what's behind. Broken shapes, broken lines ... Play with that ... [specific art-conduct]

Another way in which criteria were clearly articulated is when approval was qualified, such as in 'interesting mark-making", 'lovely colours'. Conceptual content was made clear when ideas were discussed verbally, as in the following brief excerpt from an interaction around a task in which learners were required to make a visual commentary on a public sculpture of their choice.

L: $\quad$ I found something [subject matter content] ... It's that lady on top of the fountain ... The catholic lady - I think she's catholic, I don't know [reference to a public sculpture near the school]...

L2: She's standing on top of the fountain that was erected by Howard - dedicated to someone. She's serene and like very calm and poised

L: $\quad$ So I was thinking that [of an image of serenity], with like a very destructive and grotesque background

T: $\quad$ The background being here in the Gardens [reference to a public space used for a variety of purposes] 
L3: I don't know where you get destructive and grotesque in the gardens

T: No! no! no! - you could do her in front of the school and you could let the school degenerate into this graffiti-spoilt gang-ridden [space]; she could be a visual symbol

Criteria remained unclear and open to interpretation by learners when teacher judgments were tacit such as in 'that's nice' or 'good work' (where a learner may not have recognised the aspect being praised) and when aspects to be evaluated and specialised conduct were phrased in a generalised or implicit way without exemplification. Generalised conduct-related comments such as 'get the image to balance' for instance, could be interpreted in a number of ways; conduct-specific regulative comments are not necessarily sufficient to elaborate criteria.

A third type of teacher judgment in which criteria remained unclear was specifically phrased art principles without specific recommendations for conduct or visual example, especially when visual conceptions of ideas were not shared by the teacher and learners. In the following instance, for example, the teacher discussed the principle of spatial manipulation, attempting to construct a common visual understanding which did not emerge as learners could not recall the images of which the teacher spoke.

T: [The] relation to depth in Cubism ... [There isn't really] a visible difference between foreground and background ... it seems as if it [the surface of the image] is treated very flatly but you get a very strong sense of volume ... because of shading - contrast between light and dark, it looks as if it's got volume. But you don't really know what's in front of what [specific principle articulated]. People d'you recall this?- I showed you these slides

Lastly, judgements in which teachers showed visual examples without clarifying specific features to be evaluated or conduct to be followed left criteria unclear. Teaching-and-learning linked to high levels of learner competence was found to include clear teacher judgments in over three quarters of teacher-learner interactions (Bolton, 2005).

\section{Explication of evaluation criteria in science}

In the cluster of science studies noted, one (Morais \& Miranda, 1996) examined clarification of evaluation criteria in teacher-marking of scripts: in instances where criteria were weakly framed (not elaborated by teachers), the teachers made no notations, indicating only what was correct or incorrect. Stronger framing (clarification) was provided when the teachers indicated texts which were missing; further strengthening of the framing took place when teachers actually wrote in the missing texts or corrected incorrect texts, showing where errors had been made by learners. As in the art classes, as the strength of framing of instructional discourse increased, framing of regulative discourse decreased. Examples of regulative comments decreasing in strength: from 'If you had paid attention in class, your answer would have been right...', to '.I can see you have studied.', to '.good' (Morais \& Miranda, 1996: 604).

\section{Clarity of evaluation criteria in the vocational classroom and workshop observed}

In Wedekind and Watson's (2012) description of seven teaching-learning features in the respective FET classroom and workshop observed, three of the features found by Hattie $(2003,2009)$ to make a difference to learning achievements can be linked to the clarification 
of evaluation criteria. The first is direct instruction, the second giving feedback in specific ways, and the third, mastery learning. The manner in which the FET college lecturer realised these aspects has parallels to the teaching and learning in the high-achieving science and art classes described in the present paper. It has been shown that feedback is essential for the clarification of evaluation criteria for learner success. This clarification has been characterised as extending learner understanding and elaborating on what is required (Bolton, 2005, 2009, 2012) and as providing the missing texts and providing correct texts where learner texts are incorrect (Morais et al. 1995). It appears that Wedekind and Watson's (2012) multiple types of feedback served to clarify evaluation criteria for the college learners; this feedback is categorised in relation to three learner questions, namely, Where am I going? (requiring 'feed up'); How am I going? (needing 'feed-back'); and Where to next? (needing 'feed-forward'). Wedekind and Watson (2012: 16-19) also noted two other types of feedback: questioning (testing for recall; 'knowledge of terminology'; 'understanding of deeper concepts related to the installation of wire-ways') and 'teacher immediacy' or 'responsiveness to learners' contributions'.

In the classroom and workshop settings described by Wedekind and Watson (2012), feedback was verbal and demonstrated physically. One learner bent a conduit incorrectly during the classroom demonstration observed, and again later in the workshop session. The lecturer explained verbally that the learner was incorrectly pushing the conduit against his knee instead of pulling it, showed the learner repeatedly how to bend the conduit correctly, gave him an opportunity to try again, and affirmed the learner's use of the correct action and result.

The mastery learning approach identified by Wedekind and Watson (2012: 21), with its 'repeated exhortations to practise', 'assumption that learning outcomes are attainable by all'; the 'co-operative classroom dynamic'; 'frequent and specific feedback by the teacher, in particular correcting mistakes' also clearly serves to strengthen evaluation criteria.

If one of the key ways in which evaluation criteria are explicated is through dialogue and demonstration, which include describing and modelling associated specialist behaviours, is there necessarily a specific relationship between the instructional and the regulative that enhances learner success?

\section{Embedding the instructional in the regulative for impoverished or enhanced learning}

Bernstein (1996: 29) defines the relationship between instructional and regulative discourse as one in which the instructional is embedded in, and dominated by, the regulative. The question arises: What kinds of regulative discourse enable the types of instructional discourses linked to learner success?

Regulative discourse is not necessarily clearly discernible. In instances where regulative criteria are explicit, such as in the comments 'Don't add much water to that paint, it needs to be thick enough for you to see the brushstrokes', specialised conduct is clear. In other cases, like 'Don't mix your paint quickly like that; you're going to make a mess', social norms are emphasised. However, in many instances, such as "Don't mix the paint like that", regulative comments have more than one interpretation.

In this paper, I have shown that an instructional discourse in which evaluation criteria are made explicit includes affirmation or clarification of learner actions, extension of learners' specialised selections, and elaboration of the desired way of doing things through dialogue 
and demonstration. Further, it has been shown elsewhere that teaching-learning features that aid this explication include weak classification of teacher-learner spaces, where teachers spend most lesson time amongst learners interacting with them (Bolton, 2005, 2009, 2012; Morais et al., 1992, 1995; Wedekind \& Watson, 2012). This interaction appeared to facilitate discussion of ideas and the on-going giving and receiving of feedback, thereby building understanding of evaluation criteria. In addition, strong macro-level (teacher) control of the sequencing and pacing of content and skills, described as together comprising the sizes of steps learners need to progress from existing to higher levels of knowledge and skill, is needed (Ibid.). These researchers have collectively suggested that teacher-learner dialogue, when actively opened by teachers and contributed to by learners, constitutes micro-steps within sub-processes. It appears that in the absence of open dialogue, the distances between sub-processes can be too large. They argued that open dialogue serves to assist what Muller (2000) referred to as negotiating the crossing of the boundary between every-day and esoteric (specialised) knowledge.

When communication was 'respectful', teachers were able to interrogate and shape learners' ideas and productions (Bolton, 2005, 2009, 2012). When teacher communications were 'authoritarian', learners contributed far less to classroom and ideas-related dialogue. If teachers are to help learners to build on their initial ideas and understandings, learners need to make substantial contributions to the dialogue. Dialogue depends on learners' abilities to contribute, and on teachers' abilities to understand and extend these beginnings. It appears that 'social-positional' regulative modes - communications based on the authority of the teacher as vested in his or her social position - stalled this process, while specialisedpositional speech (communications in which authority was based on specialised knowledge) furthered it (Bolton, 2005, 2009, 2012). Excerpts cited in this paper show that as explication of evaluation criteria increases, social regulative comment decreases (Bolton, 2005; Morais \& Miranda, 1996).

Bernstein's $(1971,1990,1996)$ distinction between regulative and instructional discourse is useful for differentiating between the 'rules' of specialised discourse and the 'hierarchical rules' in the teaching-learning relationship. On its own however, it is insufficient to distinguish different kinds of hierarchical relations, namely those based on the teacher's authority stemming from his or her social position, and those based on 'authority' deriving from specialised knowledge and skills and the ability to transfer these qualities. When attempting to apply these concepts in empirical research, there is room for potential slippage in the categorisation of teacher comments as being 'specialist-positional' (regulative) and as part of the features serving to clarify evaluation criteria (instructional). It has been shown that the teacher's specialist-positional 'voice' enriches the teaching-learning process and is linked to high levels of learner competence, while regulative comments based on social position alone fail to make criteria and approaches clear for learners.

\section{CONCLUDING COMMENTS}

Bernstein's (1971, 1990, 1996) distinction between instructional and regulative discourse is deeply useful for forging an external language of description that provides a means to understand and consciously manipulate power and control relations in teaching and learning 
to maximise learning. It requires conceptual elaboration however, for detailed analysis of teaching-and-learning.

Particular teaching-learning features have been found to be associated with high levels of learner competence, differing slightly but with large areas of overlap across varied knowledge areas and social class contexts (Bolton, 2005, 2009, 2012; Morais et al., 1992, 1995; Wedekind \& Watson, 2012). A particular relationship between instructional and regulative discourse - where regulative communications are inter-personal and based on teachers' specialised knowledge to enable clarification of instructional criteria - is crucial for learner success. In this paper, I attempt to analyse some of the ways in which criteria have been explicated.

While it may be important to note these particular teaching-learning features, more important still is understanding of a language of description for teaching and learning that provides means to manipulate, consciously and systematically, aspects of teaching-learning practice towards building learner competence levels in particular knowledge areas and social class contexts. What, one may ask, are the implications of these findings for policy and practice in South Africa where teacher absenteeism is high and teachers do not spend a lot of time teaching (Carnoy et al., 2012)?

First, pre-service and on-going in-service training for both teachers and managers need to emphasise that it is essential for teachers to be in their classrooms and interacting with their learners. Physical teacher or manager presence is insufficient: it is only through mutually respectful and on-going interaction that learner interrogation and deep understanding of learning is enabled.

Second, pre-service and on-going in-service training need to focus on the kind of empowering language of description addressed in this paper, and in particular on how evaluation criteria can be made clear for learners. Teachers need to understand how both instructional and regulative approaches can make a difference in blocking or enabling learning.

Third, pre-service and on-going teacher development work needs to focus on expanding teaching-and-learning and learning strategies: there are multiple ways of making evaluation criteria clear; of adjusting the selection, sequencing, and pacing of knowledge in differing contexts; and of increasing teacher knowledge to achieve the necessary levels of control. There is great need and potential for sharing particular strategies found to be linked to successful teaching and learning in specific contexts.

Finally, the language of description in the paper has potential for wider use, by the designers of official curriculum documents, by the creators and publishers of teaching-and-learning materials, and by educators and trainers across the board in the system for education, training, development and work, including across informal and non-formal contexts. Perhaps most importantly, it can be developed in what Wenger (1998: 6-7) conceptualised as 'communities of practice' - communities of educators, trainers and managers working to raise consciousness regarding power and control relations that maximise learning for both the transmission and the acquisition of learning in particular contexts. Teachers can be learners too, in such communities of practice. 


\section{ENDNOTES}

1 Harker and May's (1993) criticism of Bernstein's (1990) theory is that the concept of the elaborated code (system of context-independent meaning) is constituted as an absolute norm of linguistic practices, while the restricted code (system of context-dependent meaning) involves deprivation or inability to use an elaborated code has been refuted by pointing to the fact that individuals across a range a social contexts can learn to use differing codes (Bolton, 2005).

2 The two modules observed were stand-alone Sector Education and Training Authority (SETA)-accredited skills programmes targeted at a small number of young adults not otherwise studying or working, and from a low socio-economic area. Most of the learners had left school before successfully completing the twelve years required for a school-leaving certificate. They had responded to a community-newspaper advertisement placed by the FET college, in which a subsidised opportunity to enrol in a six-month basic electrical skills course was offered.

3 Several other studies use Bernstein's (1996) concepts of classification and framing to describe pedagogy at the level of the school (Daniels, 1988, 1989, 1995; Sadovnik \& Semel, 2000); the relations between pedagogy, social context, and learners' orientation to meaning (Daniels, 1989; Hoadley, 2005), and outcomes (Daniels, 1995; Sadovnik \& Semel, 2000); and the relative significance of pedagogy and opportunities to learn (Reeves 2005). The specific foci of these projects lie outside the scope of the current paper.

4 For fuller accounts of these findings see Domingos, 1987, 1989; Morais et al., 1992, 1995; Morais \& Camara, 1997; Morais \& Neves, 1997; Morais \& Rocha, 1997; Morais, 1998; Bolton, 2005; Morais \& Pires, 2002; Ferreira \& Morais, 2008; Bolton. 2005, 2009, 2012; Wedekind \& Watson, 2012.

5 Regulative discourse was also described in terms of movement within and between classrooms; the initiation and extension of dialogue; and control of sound levels and work-focus (Bolton, 2005); the main focus in the current paper is on the regulative mode consistently linked to high learner achievement, and its relationship with instructional discourse.

6 Transgressions included for instance having drawn incorrectly by not showing graded shading, inferred from a teachers' comment "that's very flat, work it a bit more", and holding a brush incorrectly, as meant in "don't hold your brush like that". Social transgressions such as learners chatting rather than working were usually more obvious, even when norms were implicit as in a teacher's comment "Hey!".

7 In the table 'inter-personal' and 'art-positional' comments, often occurring together and both suggesting 'respectful' relations between teacher and learner, have been grouped, as have 'social-positional' and 'imperative' comments, these comments seen to suggest 'authoritarian' relations.

8 Details relating to teaching-and-learning in the classroom and workshop of an electrical-skills lecturer at a Further Education and Training (FET) college is taken from a single case study (Wedekind \& Watson 2012). The subject of the study - the lecturer - was teaching two Adult Basic Education and Training (ABET) modules at National Qualifications Framework (NQF) Level 2 (Organising Framework for Occupations (OFO) Level 8): Design and construct a single phase circuit and Installing wire-ways.

\section{REFERENCES}

ANYON, J. 1981. Social class and school knowledge. Curriculum Inquiry, 11(1):3-42.

BERNSTEIN, B. 1971. Class, codes and control, Volume 1: Theoretical studies towards a sociology of language. London, UK: Routledge and Kegan Paul.

BERNSTEIN, B. 1975. Class, codes and control, Volume 3: Towards a theory of educational transmissions. London, UK: Routledge and Kegan Paul.

BERNSTEIN, B. 1981. On the classification and framing of educational knowledge. In Young, M.F.D. (Ed.), Knowledge and control. London: MacMillan. 47-69.

BERNSTEIN, B. 1990. Class, codes and control, Volume 4: The structuring of pedagogic discourse. London, UK: Routledge.

BERNSTEIN, B. 1996. Pedagogy, symbolic control, and identity. London, UK: Taylor and Francis.

BOLTON, H. 2005. Social class, pedagogy, and achievement in art. Doctoral dissertation. Cape Town, South Africa: University of Cape Town. 
BOLTON, H. 2007. Pedagogy, subjectivity, and mapping judgment in art, a weakly structured field of knowledge. Journal of Education, 40:59-78.

BOLTON, H. 2009. What really matters: Aspects of pedagogy linked to access to and achievement in specialised knowledge for learners in differing social class contexts. Journal of Education, 47:101-126.

BOLTON, H. 2012. Developing educational standards through quality teaching and learning. Paper submitted for the proceedings of the conference Standards in Education: The Challenge, hosted by Umalusi: Council for Quality Assurance in General and Further Education and Training, Gauteng, South Africa, 10-12 May 2012.

CARNOY, M, L Chisholm \& B Chilisa. 2012. The low achievement trap: Comparing schooling in Botswana and South Africa. Pretoria, RSA: Human Sciences Research Council (HSRC) Press.

COLEMAN, JS. 1966. Equality of Educational Opportunity. Report from the US Government Printing Office, Washington.

CONNELL, RW. 1974. The causes of educational inequality: Further observations. Australian and New Zealand Journal of Sociology, 10:186-189.

DA SILVA, TT. 1988. Distribution of school knowledge and social reproduction in a Brazilian urban setting. British Journal of Sociology of Education, 9(1):55-79.

DANIELS, H. 1988. An enquiry into the different forms of special school organisation, pedagogic practise, and pupil discrimination. Doctoral dissertation. CORE (Collected Resources in Education) 12(2).

DANIELS, H. 1989. Visual displays as tacit relays of the structure of pedagogic practise. British Journal of Sociology of Education, 10(2):123-140.

DOMINGOS, AM. 1987. Social class, pedagogic practise and achievement in science: A study of secondary schools in Portugal. Doctoral dissertation. CORE (Collected Resources in Education) 11(2).

DOMINGOS, AM. 1989. Influence of the social context of the school on the teachers' pedagogic practise. British Journal of Sociology of Education, 10(3):351-366.

ENGESTRÖM, Y. 1987. Learning by expanding: An activity-theoretical approach to developmental research. Orienta-Konsultit, Helsinki. Available at http://lchc.ucsd.edu/MCA/Paper/ Engestrom/ expanding/toc.htm).

ENGESTRÖM, Y. 2001. Expansive learning at work: Toward an activity theoretical reconceptualisation. Journal of Education and Work, 14(1): 133-156.

FENWICK, T. 2010a. Reclaiming and re-embodying experiential learning through Complexity Science. Studies in the Education of Adults, 3(2): 123-141.

FENWICK, T. 2010b. Rethinking the "thing": Socio-material approaches to understanding and researching learning in work. Journal of Workplace Learning, 22(1-2):104-116.

FENWICK, T. 2010c. Workplace 'learning' and adult education: Messy objects, blurry maps and making difference. Draft paper submitted for the South African Qualifications Authority (SAQA) Research Seminar: Theorizing work and learning - an evolving narrative, 14 October 2010, Pretoria, South Africa.

FERREIRA, S, AM Morais \& I Neves. 2008. Science curricula and design: Analysis of authors' ideological and pedagogical principles. Paper presented at the 5th Basil Bernstein Symposium. Cardiff, Wales, 9-12 July 2008. 
HATTIE, JAC. 2003. Teachers make a difference: What is the research evidence? Keynote presentation at the ACER Annual Conference: Building Teacher Quality, Melbourne, Australia, October 2003.

HATTIE, JAC. 2009. Visible learning: A synthesis of over 800 meta-analyses related to achievement. Oxford, UK: Routledge.

HOADLEY, U. 2005. Social class, pedagogy, and the specialisation of voice in four South African primary schools. Doctoral dissertation. Cape Town, South Africa: University of Cape Town.

MORAIS, AM 1998. To succeed in the classroom context: Acquisition of recognition and realisation rules. Seminar given at the Instituto de Educacion y Pedagogica, Universidad del Valla, Cali, Colombia. Also published as Morais, A.M. 1999. Desenvolvimento cientifico e aquisicao do texto legitimo: alguns aspectos da sociologica da aprendizagem. Revista Portuguesa da Educacao, 12(2):197-225.

MORAIS, AM \& C MIRANDA. 1996. Understanding teachers' evaluation criteria: a condition for success in science classes. Journal of Research in Science Teaching, 33(6):601-624.

MORAIS, AM \& MJ CAMARA. 1997. Science in kindergarten: The sociology of learning in the classroom. Mimeo obtained from the author. Also published as Camara, M. J. 1998. O desenvolvimento cientifico no jardim de infancia: influencia de praticas pedagogicas. Revista de Educacao, 7(2):179-199.

MORAIS, AM \& IP NEVES. 1997. Pedagogic discourse in family and school - models for analysis. In Pedro, E., Discourse analysis. Proceedings of the First International Conference on Discourse Analysis. Lisbon, Portugal: Edicoes Colibri/APL.

MORAIS, AM \& C ROCHA. 1997. Development of social competences in the primary school - a study of specific pedagogic practises. Paper presented at the Seventh Conference of EARLI European Association for Research in Learning and Instruction, University of Athens, Greece. Also published as Morais, AM \& C Rocha. 2000. Development of social competences in the primary school - a study of specific pedagogic practises. British Educational Research Journal, 6(1):93-120.

MORAIS, AM \& D PIRES. 2002. The what and the how of teaching and learning: going deeper into sociological analysis and intervention. Paper presented at the Second International Basil Bernstein Symposium, Cape Town, South Africa. Also published as Morais, AM, I.P Neves \& D Pires. 2004. The what and the how of teaching and learning: going deeper into sociological analysis and intervention. In Muller, J, B Davies \& AM Morais,. (Eds), Reading Bernstein, researching Bernstein (Chapter 6). London, UK: Routledge and Falmer.

MORAIS, AM, F FONTINHAS \& I NEVES. 1992. Recognition and realisation rules in acquiring school science - the contribution of pedagogy and social background of students. British Journal of Sociology of Education, 13(2):247-270.

MORAIS, AM, IP NEVES, H, ANTUNES, F FONTINHAS, A MEDEIROS \& D PENEDA. 1995. Pedagogic practises for equality: A study of the relation between learning contexts and students' learning. Paper presented at the European Conference on Educational Research 1995, University of Bath, United Kingdom. Also published as Morais, AM, IP Neves, H Antunes, F Fontinhas, A Medeiros \& D Peneda. 1996. Practicas pedagogicas e aprendizagem cientifica: um estudo sociologico. Revista de Educacao, 5(2):69-93.

MULLER, JP. 2000. Reclaiming knowledge. London, UK: Routledge Falmer.

PEDRO, ER. 1981. Social stratification and classroom discourse: a sociolinguistic analysis of classroom practice. Stockholm, Sweden: Stockholm Institute of Education, Department of Educational Research. 
REEVES, C. 2005. The effect of opportunity-to-learn pedagogy on Mathematics achievement in schools serving low socio-economic status communities in the Cape Peninsula. Doctoral thesis, University of Cape Town, South Africa.

SADOVNIK, A \& S SEMEL., 2000. Basil Bernstein's theory of pedagogic practice: Historical and sociological analysis of urban and suburban schools in the New York metropolitan area. Paper delivered at the First Basil Bernstein Symposium, Lisbon, Portugal, June 2000

TAYLOR, N., J MULLER \& P VINJEVOLD. 2003. Getting schools working: research and systemic school reform in South Africa. (Chapter 4: Factors which influence learner performance). Cape Town, RSA: Maskew Miller Longman.

WEDEKIND, V. \& A WATSON. 2012. Being the visible difference: An analysis of a FET college lecturer at work. Paper in press.

WENGER, E. 1998. Communities of practice: Learning, meaning, and identity. New York, NY: Cambridge University Press.

\section{BIOGRAPHIC NOTE}

Dr Heidi Bolton is the Director: Research at the South African Qualifications Authority (SAQA). She oversees SAQAs long-term research partnership projects towards implementation and further development of the National Qualifications Framework (NQF), assessing the effectiveness of the NQF, and generating research-based advice for the Minister of Higher Education and Training. She also oversees 'current-response' projects, publishing and work-shopping research findings; and organizing national NQF research events.

Email address: HBolton@saqa.co.za. 